\title{
Możliwości eksportowania przez polskie przedsiębiorstwa na rynki wybranych krajów Afryki Subsaharyjskiej
}

\author{
Monika Grottel* iD \\ Anna Sperska** iD
}

\section{Streszczenie}

W artykule podjęto próbę przybliżenia możliwości, przed jakimi stoją polskie przedsiębiorstwa planujące ekspansję zagraniczną i eksport na rynki krajów Afryki Subsaharyjskiej. Z analizy wybranych obszarów gospodarczo-społecznych krajów subsaharyjskich wynika, że mimo dużego zróżnicowania oraz utrzymującej się niestabilności politycznej, społecznej i gospodarczej rozwój gospodarczy tego regionu postępuje w szybkim tempie. Zdaniem ekspertów rynki ASS to rynki obiecujące, które w ciągu dekady staną się atrakcyjnym pod względem gospodarczym regionem świata, a w niedalekiej przyszłości wyprzedzą gospodarki BRICS i będą napędzać wzrost gospodarczy na świecie. Po przeanalizowaniu polskiego eksportu do krajów ASS można stwierdzić, że polskie przedsiębiorstwa nie wykorzystują potencjału eksportowego na rynki tego regionu. Autorki tekstu wskazują główne przyczyny takiego stanu rzeczy oraz formułują zalecenia dotyczące eksportu do krajów ASS. W zaleceniach zwrócono szczególną uwagę na konieczność odpowiedniego przygotowania strategii eksportowej, a następnie procesu eksportowego ze szczególnym uwzględnieniem różnic kulturowych. Ponadto scharakteryzowano obszary

* Monika Grottel - dr, Uniwersytet Gdański, Wydział Ekonomiczny, Katedra Biznesu Międzynarodowego, ORCID: 0000-0002-2197-8978, monika.grottel@ug.edu.pl

** Anna Sperska - dr, Uniwersytet Gdański, Wydział Ekonomiczny, Katedra Biznesu Międzynarodowego, ORCID: 0000-0002-5940-0784, anna.sperska@ug.edu.pl 
obarczone największym ryzykiem, będące jednocześnie obszarami kluczowymi, stanowiącymi o powodzeniu ekspansji eksportowej na rynki Afryki Subsaharyjskiej.

Slowa kluczowe: eksport, Polska, Afryka Subsaharyjska, wzrost gospodarczy, strategia eksportowa, strategia marketingowa

JEL: F14, F17, O55

\section{Wstęp}

Kraje Afryki Subsaharyjskiej (ASS) określane są mianem elity krajów Czarnego Lądu, ,afrykańskimi lwami”, które coraz szybciej zmniejszają dystans do rozwiniętego świata (Kowalik 2017). Eksperci Banku Światowego szacują, że jeśli obecne tempo wzrostu gospodarczego utrzyma się, to większość krajów regionu osiągnie status krajów o „średnim dochodzie” do 2025 r. i stanie się motorem wzrostu gospodarczego na świecie. Rynki krajów subsaharyjskich stwarzają coraz więcej możliwości, które przyciągają inwestorów i eksporterów z wielu krajów rozwiniętych, jednak mimo utrzymujących się na wysokim poziomie wskaźników gospodarczych, coraz wyższych lokat w rankingach międzynarodowych, a także rekomendacji i wsparcia polskiego rządu, kraje ASS nadal nie odgrywają istotnej roli w eksporcie Polski.

Celem opracowania jest zwrócenie uwagi na możliwości rozwijania aktywności eksportowej polskich przedsiębiorstw na wybranych rynkach Afryki Subsaharyjskiej oraz sformułowanie wytycznych dla potencjalnych eksporterów.

Opracowanie składa się z trzech części. W pierwszej z nich przeanalizowano główne wskaźniki ekonomiczne wybranych krajów ASS w latach 20052019 oraz wskazano ich mocne i słabe strony jako rynków eksportowych dla polskich przedsiębiorstw. Przedmiotem drugiej części jest aktywność polskich przedsiębiorstw na badanych rynkach. Przedstawiono w niej również branże o dużym potencjale rozwojowym oraz przykłady przedsiębiorstw skutecznie realizujących strategię rozwoju na rynkach subsaharyjskich. Wartość dodaną opracowania stanowią sformułowane w części trzeciej praktyczne zalecenia dla polskich przedsiębiorców planujących ekspansję na rynki krajów Afryki Subsaharyjskiej. Wskazano w nich determinanty skutecznej strategii marketingowej - w tym zagadnienia związane z różnicami kulturowymi, poszukiwaniem kontrahentów oraz weryfikacją ich wiarygodności - i przeanalizowano problemy z organizacją dostaw na rynki afrykańskie oraz zakres pomocy instytucjonalnej, na jaką mogą liczyć polscy eksporterzy. 
Na potrzeby opracowania przeprowadzono analizę źródeł literaturowych, dokumentów urzędowych oraz danych gospodarczych zaczerpniętych z baz krajowych i zagranicznych, dokonano syntezy informacji publikowanych w raportach krajowych i międzynarodowych ${ }^{1}$. Wykorzystano w nim także wyniki obserwacji i doświadczenia własne autorek.

\section{Charakterystyka wybranych rynków Afryki Subsaharyjskiej jako perspektywicznego kierunku dla polskiego eksportu}

Afryka Subsaharyjska jest regionem wielu prędkości, w którym szybkie tempo wzrostu gospodarczego idzie w parze z najwyższymi w skali świata wskaźnikami ubóstwa. Zgodnie z danymi opublikowanymi przez Bank Światowy i Międzynarodowy Fundusz Walutowy, na liście 25 najbiedniejszych krajów świata znalazły się 22 kraje afrykańskie - wszystkie z Afryki Subsaharyjskiej². Raport Banku Światowego ze stycznia 2019 r., dotyczący tempa wzrostu gospodarczego na świecie, wykazuje jednocześnie, że 13 spośród 61 najszybciej rozwijających się krajów świata to również kraje $\mathrm{ASS}^{3}$ (Tabela 1). W ostatnich latach sytuacja gospodarcza w wielu krajach regionu - mimo problemów finansowych i wielomilionowych długów, które przez lata ograniczały rozwój gospodarczy tych krajów (Munyama 2011, s. 66) - dynamicznie się zmienia, wzrasta popyt na dobra konsumpcyjne oraz zapotrzebowanie na zaawansowane technologie, innowacyjne maszyny i urządzenia oraz usługi. W związku $\mathrm{z}$ tym dyskusja na temat szans i możliwości, jakie rynki tego regionu stwarzają zagranicznym inwestorom i eksporterom, staje się coraz bardziej ożywiona

Rekomendacje dla polskich przedsiębiorców planujących eksport na rynki subsaharyjskie zostaną sformułowane na podstawie analizy mocnych i słabych stron regionu. Na wstępie należy podkreślić, że rynek subsaharyjski jest bardzo zróżnicowany, składa się z krajów o niskim, średnio-niskim, średnim i wysokim dochodzie, z których prawie połowa to gospodarki dotknięte konfliktami

\footnotetext{
${ }^{1}$ W opracowaniu wykorzystano dane statystyczne Banku Światowego, Banku Światowego w Afryce, Afrykańskiego Banku Rozwoju, Konferencja Narodów Zjednoczonych ds. Handlu i Rozwoju (ang. United Nations Conference on Trade and Development, UNCTAD), Organizacji Narodów Zjednoczonych, Międzynarodowego Funduszu Walutowego (ang. International Monetary Fund, IMF), Głównego Urzędu Statystycznego (GUS) oraz materiały i diagnozy Polskiej Agencji Inwestycji i Handlu (PAIiH) oraz Korporacji Ubezpieczeń Kredytów Eksportowych (KUKE).

${ }^{2}$ Najbiedniejsze kraje Afryki Subsaharyjskiej to: Benin, Gwinea, Mali, Rwanda, Czad, Etiopia, Zimbabwe, Uganda, Burkina Faso, Gwinea Bissau, Gambia, Togo, Komory, Madagaskar, Sierra Leone, Mozambik, Malawi, Niger, Demokratyczna Republika Kongo, Burundi, Republika Środkowoafrykańska, Liberia (Bank Światowy 2020).

${ }^{3}$ Sześć spośród 10 najszybciej rozwijających się gospodarek świata to kraje subsaharyjskie (Bank Światowy 2020).
} 
wewnętrznymi, niestabilne, o wysokim ryzyku transakcyjnym (Bank Światowy w Afryce 2020). Z drugiej strony gospodarki, które odnotowują szybkie tempo wzrostu, są coraz bardziej przewidywalne i zyskują w rankingach międzynarodowych (Kopiński i in. 2017; McKinsey Global Institute 2016). Formułując konkretne zalecenia dla potencjalnych eksporterów, warto skupić się na jednym państwie lub wybranej grupie państw, dlatego w dalszej części opracowania przeanalizowano te spośród najszybciej rozwijających się krajów regionu, które w ocenie autorek opracowania stwarzają największe możliwości dla polskich eksporterów.

Do mocnych stron wybranych krajów ASS zaliczają się: wzrost gospodarczy, czynnik demograficzny, rosnąca skłonność do importu oraz brak infrastruktury w wielu obszarach życia społecznego tj. opieki zdrowotnej, budownictwa mieszkaniowego, telekomunikacji i komunikacji. Ten ostatni czynnik jest wprawdzie słabą stroną regionu, jednak daje on duże możliwości eksportowe producentom, dostawcom maszyn, wyposażenia, oprogramowania i usług.

Przeprowadzona analiza pokazuje, że w przypadku najdynamiczniej rozwijających się krajów ASS za utrzymującym się od lat szybkim tempem wzrostu gospodarczego podąża dodatnia dynamika wzrostu PKB per capita (Tabele 2, 3). W 2009 r., w czasie postępującego na świecie kryzysu, PKB krajów afrykańskich zwiększyło się o 3\%, a od 2013 r. kraje ASS odnotowują największy wzrost gospodarczy na świecie ze średnim rocznym wzrostem PKB na poziomie 5,6\%. W latach 2000-2015 Afryka Subsaharyjska odnotowywała wyższy roczny wzrost PKB niż UE i świat (Tabela 1), co budziło jednak spore obawy, ponieważ uważano, że dynamika wzrostu w latach 2004-2014 wynikała z boomu eksportu surowców oraz miliardowych inwestycji Chin w przemysł wydobywczy (Gostomski, Michałowski 2018, s. 121-131; Rynarzewski i in. 2017, s. 55), więc nie mogła być trwała. W latach 2013-2018 średnie roczne tempo wzrostu gospodarki krajów ASS przewyższało średnie PKB krajów UE i było zbliżone do średniej światowej (Tabela 1), a pod koniec 2019 r. utrzymało się na poziomie 4-5\%. Według raportu Afrykańskiego Banku Rozwoju (2020) wskaźnik ten ma przekroczyć 6\% do 2023 r.

Tabela 1. Średnie roczne tempo wzrostu gospodarczego (w \%) w wybranych regionach świata

\begin{tabular}{|l|c|c|c|c|}
\hline \multicolumn{1}{|c|}{ Region } & $\mathbf{2 0 0 0 - 2 0 0 5}$ & $\mathbf{2 0 0 5 - 2 0 1 0}$ & $\mathbf{2 0 1 0 - 2 0 1 5}$ & $\mathbf{2 0 1 3 - 2 0 1 8}$ \\
\hline Świat & 3,10 & 2,26 & 2,73 & 2,79 \\
\hline Unia Europejska & 1,86 & 0,59 & 0,96 & 2,14 \\
\hline Afryka & 5,69 & 5,15 & 3,26 & 2,64 \\
\hline Afryka Subsaharyjska & 6,12 & 5,21 & 4,65 & 2,53 \\
\hline
\end{tabular}

Źródło: opracowanie własne na podstawie UNCTAD 2020a.

W latach 2000-2005 najwyższy wskaźnik wzrostu PKB osiągnęła Nigeria $(11,32 \%)$, od 2018 r. uznawana za największą gospodarkę świata pod względem nominalnego PKB (Tabela 2). W 2019 r. najdynamiczniej rozwijającym 
się regionem kontynentu była wschodnia część ASS (5\%) (Afrykański Bank Rozwoju 2019), w której najszybszy wzrost odnotowały Rwanda, Etiopia i Tanzania (Tabela 2). Zachodnia część ASS osiągnęła wzrost na poziomie 3,5\%, a jej najsilniejszymi gospodarkami są Ghana, w przypadku której wzrost napędzają sektor wydobywczy, głównie ropy naftowej, i rolnictwo, oraz Wybrzeże Kości Słoniowej - tutaj czynnikiem wzrostu są inwestycje publiczne. Jeśli chodzi o środkową część ASS, to w jej przypadku wzrost w 2019 r. wyniósł 3,2\%, a jego najwolniejsze tempo - spowodowane spadkiem cen surowców ${ }^{4}$ - odnotowano w 2016 r. (Kopiński i in. 2017). W latach 2018-2019 niemal we wszystkich krajach środkowej części ASS nastąpił wzrost gospodarczy. Wyjątkiem była Demokratyczna Republika Konga, w której w 2019 r. z powodu epidemii wirusa eboli nastąpił spadek do 4,5\%. Najniższy poziom wzrostu gospodarczego w 2019 r. odnotowano w krajach południowej części ASS, w tym w Mozambi$\mathrm{ku}$, gdzie w wyniku poważnych zniszczeń infrastruktury i rolnictwa na skutek cyklonu (Afrykański Bank Rozwoju 2020) PKB spadło z 6,7\% w 2015 r. do $2,2 \%$ w 2019 r. (Tabela 2).

Tabela 2. Nominalne PKB i tempo wzrostu najszybciej rozwijających się krajów Afryki Subsaharyjskiej (w mln USD)

\begin{tabular}{|l|r|r|r|r|r|r|r|r|}
\hline \multirow{2}{*}{ Kraj } & \multicolumn{2}{|c|}{$\mathbf{2 0 0 5}$} & \multicolumn{2}{c|}{$\mathbf{2 0 1 0}$} & \multicolumn{2}{c|}{$\mathbf{2 0 1 5}$} & \multicolumn{2}{c|}{$\mathbf{2 0 1 9}$} \\
\cline { 2 - 10 } & $\begin{array}{c}\text { wartość } \\
\text { PKB }\end{array}$ & $\begin{array}{c}\text { PKB } \\
\mathbf{9}\end{array}$ & $\begin{array}{c}\text { wartość } \\
\text { PKB }\end{array}$ & $\begin{array}{c}\text { PKB } \\
\mathbf{\%}\end{array}$ & $\begin{array}{c}\text { wartość } \\
\text { PKB }\end{array}$ & $\begin{array}{c}\text { PKB } \\
\text { \% }\end{array}$ & $\begin{array}{c}\text { wartość } \\
\text { PKB }\end{array}$ & $\begin{array}{l}\text { PKB } \\
\mathbf{\%}\end{array}$ \\
\hline Afryka & 1127604 & & 1968455 & & 2306279 & & 2542226 & \\
\hline $\begin{array}{l}\text { Afryka } \\
\text { Subsaharyjska }\end{array}$ & 754498 & & 1304742 & & 1576604 & & 1813720 & \\
\hline Etiopia & 12164 & $\mathbf{1 1 , 8}$ & 26311 & $\mathbf{1 2 , 6}$ & 63079 & $\mathbf{1 0 , 4}$ & 95197 & 8,5 \\
\hline Rwanda & 2581 & $\mathbf{9 , 4}$ & 5772 & $\mathbf{7 , 3}$ & 8278 & $\mathbf{8 , 9}$ & 10295 & 9,4 \\
\hline $\begin{array}{l}\text { Wybrzeże } \\
\text { Kości Słoniowej }\end{array}$ & 17085 & $\mathbf{1 , 7}$ & 24885 & $\mathbf{2 , 0}$ & 33119 & $\mathbf{8 , 8}$ & 43163 & 6,9 \\
\hline Dżibuti & 709 & $\mathbf{3 , 6}$ & 1244 & $\mathbf{1 1 , 7}$ & 2445 & $\mathbf{7 , 7}$ & 3225 & 6,7 \\
\hline Ghana & 22765 & $\mathbf{6 , 2}$ & 42587 & $\mathbf{7 , 9}$ & 49182 & $\mathbf{2 , 2}$ & 65494 & 6,1 \\
\hline $\begin{array}{l}\text { Zjednoczona } \\
\text { Republika } \\
\text { Tanzanii }\end{array}$ & 17611 & $\mathbf{7 , 3}$ & 32370 & $\mathbf{6 , 3}$ & 40562 & $\mathbf{6 , 2}$ & 64133 & 7,0 \\
\hline Senegal & 11267 & $\mathbf{5 , 6}$ & 16725 & $\mathbf{4 , 2}$ & 17761 & $\mathbf{6 , 4}$ & 24162 & 5,2 \\
\hline Niger & 4489 & $\mathbf{7 , 4}$ & 7620 & $\mathbf{8 , 4}$ & 9659 & $\mathbf{4 , 3}$ & 12527 & 5,7 \\
\hline Benin & 4804 & 1,7 & 6970 & 2,1 & 8454 & 6,5 & 10403 & 6,4 \\
\hline Uganda & 11158 & $\mathbf{1 0 , 0}$ & 19683 & $\mathbf{8 , 2}$ & 25098 & $\mathbf{5 , 7}$ & 32863 & 5,5 \\
\hline Burkina Faso & 6144 & 8,7 & 10100 & 8,5 & 11823 & 3,9 & 15738 & 5,9 \\
\hline Gwinea & 4063 & $\mathbf{3 , 0}$ & 6853 & $\mathbf{4 , 8}$ & 8794 & $\mathbf{3 , 8}$ & 13252 & 6,0 \\
\hline Kenia & 21506 & $\mathbf{5 , 9}$ & 40000 & $\mathbf{8 , 4}$ & 64008 & $\mathbf{5 , 7}$ & 97050 & 5,7 \\
\hline
\end{tabular}

${ }^{4}$ W 2014 r. cena ropy naftowej wynosiła 93 USD za baryłkę, w 2016 r. spadła do 43 USD (Macrotrends 2020). 
Tabela 2. (cd.)

\begin{tabular}{|l|r|r|r|r|r|r|r|r|}
\hline Nigeria & $\mathbf{1 7 6 ~ 1 3 4}$ & 6,4 & $\mathbf{3 6 3 ~ 3 6 0}$ & 8,0 & $\mathbf{4 9 4} \mathbf{5 8 3}$ & 2,7 & $\mathbf{4 7 8 ~ 9 2 3}$ & 2,2 \\
\hline $\begin{array}{l}\text { Demokratyczna } \\
\text { Republika } \\
\text { Konga }\end{array}$ & 11965 & 6,1 & 21566 & 7,1 & 37918 & 6,9 & 50827 & 4,5 \\
\hline Mozambik & 8459 & 6,6 & 11121 & 6,5 & 15951 & 6,7 & 14926 & 2,2 \\
\hline Świat & $\mathbf{4 7 6 0 5 ~ 0 3 8}$ & & $\mathbf{6 6 ~ 2 3 1 ~ 8 2 9}$ & & $\mathbf{7 4 ~ 8 8 2 ~ 6 4 8}$ & & $\mathbf{8 7 ~ 6 9 1 ~ 5 0 1}$ & \\
\hline
\end{tabular}

Źródło: opracowanie własne na podstawie UNCTAD 2020 b.

Tabela 3. PKB per capita i dynamika zmian (2019 w porównaniu z 2005) w najszybciej rozwijających się krajach Afryki Subsaharyjskiej (w mln USD)

\begin{tabular}{|c|c|c|c|c|c|}
\hline Kraj & 2005 & 2010 & 2015 & 2019 & $\begin{array}{c}2005=100 \\
(\% \text { w } 2019 \\
\text { względem 2005) }\end{array}$ \\
\hline Europa & 22036 & 26901 & 25712 & 28674 & 130 \\
\hline Afryka & 1233 & 1897 & 1953 & 1946 & 158 \\
\hline ASS & 1046 & 1580 & 1647 & 1703 & 163 \\
\hline Etiopia & 159 & 300 & 626 & 849 & 534 \\
\hline Rwanda & 292 & 575 & 728 & 815 & 279 \\
\hline Wybrzeże Kości Słoniowej & 931 & 1212 & 1426 & 1678 & 180 \\
\hline Dżibuti & 905 & 1480 & 2676 & 3312 & 366 \\
\hline Ghana & 1044 & 1719 & 1766 & 2153 & 206 \\
\hline $\begin{array}{l}\text { Zjednoczona Republika } \\
\text { Tanzanii }\end{array}$ & 458 & 730 & 943 & 1109 & 242 \\
\hline Senegal & 1016 & 1319 & 1218 & 1483 & 146 \\
\hline Niger & 330 & 463 & 483 & 537 & 163 \\
\hline Benin & 602 & 758 & 799 & 882 & 147 \\
\hline Uganda & 403 & 607 & 657 & 742 & 184 \\
\hline Burkina Faso & 458 & 647 & 653 & 774 & 169 \\
\hline Gwinea & 446 & 672 & 769 & 1083 & 243 \\
\hline Kenia & 587 & 952 & 1337 & 1846 & 314 \\
\hline Nigeria & 1268 & 2292 & 2730 & 2383 & 188 \\
\hline $\begin{array}{l}\text { Demokratyczna Republika } \\
\text { Konga }\end{array}$ & 218 & 334 & 497 & 586 & 269 \\
\hline Mozambik & 413 & 473 & 590 & 492 & 119 \\
\hline Niemcy & 41948 & 38855 & 44300 & 41577 & 99 \\
\hline Wielka Brytania & 34873 & 42020 & 41089 & 45731 & 131 \\
\hline Czechy & 13285 & 19691 & 17623 & 22932 & 173 \\
\hline
\end{tabular}

Źródło: opracowanie własne na podstawie UNCTAD 2020 b.

Podsumowując, można stwierdzić, że w latach 2005-2019 najsilniejsze gospodarki ASS odnotowały dynamiczny wzrost. Miały na to wpływ uwarunkowania wewnętrzne, tj. rosnący popyt wewnętrzny i konsumpcja prywatna wynikająca z dużej dynamiki PKB per capita (Tabela 3), rozwój infrastruktury i dążenie do stabilizacji wewnętrznej. Kraje regionu otworzyły się również na 
rozwój bilateralnej współpracy handlowej oraz inwestycje zagraniczne (Gostomski, Michałowski 2018, s. 121-131; Zajączkowski 2016). Analizując kondycję gospodarczą krajów ASS, trzeba jednak pamiętać, że PKB nie jest dokładnym jej miernikiem. Powszechnie stosowane PKB per capita oraz metoda parytetu siły nabywczej nie uwzględniają bowiem elementów świadczących o dobrobycie i rozwoju społecznym - tj. dostępu do edukacji i służby zdrowia, długości życia czy poziomu zanieczyszczenia środowiska - nie odzwierciedlają jakości usług ani nie uwzględniają faktu, że część PKB jest transferowana w formie zysków za granicę. Uwzględniane są za to wydatki na używki, administrację i obronę narodową. W dalszej części opracowania przedstawiono zatem również słabe strony regionu, tj. wysoki poziom ubóstwa, konflikty wewnętrzne, niestabilność polityczną oraz niski poziom rozwoju infrastruktury.

Odnosząc się do najnowszych danych dotyczących rozprzestrzeniającej się od końca 2019 r. pandemii koronawirusa, należy zauważyć, że globalny zasięg pandemii ma negatywny wpływ na życie i gospodarkę regionu (Bank Światowy w Afryce 2020). Przewiduje się, że w 2020 r. nastąpi spadek aktywności gospodarczej o 3,3\%. Mniejsza konsumpcja krajowa oraz ograniczenie inwestycji wskutek podejmowania działań mających na celu powstrzymanie rozprzestrzeniania się wirusa będą skutkować spowolnieniem działalności gospodarczej (szacuje się, że straty w produkcji w 2021 r. wyniosą 115 mld USD), co może doprowadzić $40 \mathrm{mln}$ osób do skrajnego ubóstwa, a zamknięcie szkół i straty w nauce, które dotkną $253 \mathrm{mln}$ uczniów, mogą zahamować postęp w budowaniu kapitału ludzkiego.

Czynnikiem, który pozytywnie wpłynie na dalszy rozwój gospodarczy regionu ASS i powinien zachęcać polskich producentów do eksportowania na te rynki, jest największa na świecie strefa wolnego handlu - Afrykańska Kontynentalna Strefa Wolnego Handlu (ang. African Continental Free Trade Area, AfCFTA) ${ }^{5}$, działająca od stycznia 2021 r. (Costa 2020).

O możliwościach eksportowych na wybrane rynki istotnie decyduje ich skłonność do importu (Tabela 4). Zdecydowana większość towarów importowanych do ASS pochodzi z krajów afrykańskich (UNCTAD 2020b). Oprócz nich głównymi dostawcami są Chiny, Stany Zjednoczone Ameryki i Zjednoczone Emiraty Arabskie, a z Europy - Niemcy, Holandia i Francja. W latach 2005-2015 w przypadku wszystkich głównych dostawców nastąpił wzrost wartości eksportu do ASS, a od 2015 r. wartość ta utrzymuje się na stałym poziomie. Podobnie jest w przypadku udziału procentowego krajów ASS w ogólnym eksporcie jej głównych dostawców. Wyjątkiem są Chiny, które z roku na rok zwiększają swoje zaangażowanie w regionie (UNCTAD 2020b).

5 AfCFTA, utworzona w 2018 r. na mocy Afrykańskiej kontynentalnej umowy o wolnym handlu między 54 z 55 krajów Unii Afrykańskiej, określa strategiczne ramy zrównoważonego rozwoju Afryki sprzyjającego włączeniu społecznemu wszystkich obywateli. Więcej na oficjalnej stronie Unii Afrykańskiej: https://au.int/en/cfta. 
Tabela 4. Wartość importu towarów i dynamika zmian w wybranych krajach Afryki Subsaharyjskiej w latach 2005-2019 (w mln USD)

\begin{tabular}{|l|r|r|r|r|r|}
\hline \multicolumn{1}{|c|}{ Kraj } & $\mathbf{2 0 0 5}$ & $\mathbf{2 0 1 0}$ & $\mathbf{2 0 1 5}$ & $\mathbf{2 0 1 9}$ & $\begin{array}{c}\text { 2005 } \mathbf{1 0 0} \\
\text { (\% w 2019 } \\
\text { względem 2005) }\end{array}$ \\
\hline Etiopia & 4095 & 8602 & 16702 & 14554 & \multicolumn{1}{c|}{355} \\
\hline Rwanda & 430 & 1431 & 2382 & 2703 & 629 \\
\hline Wybrzeże Kości Słoniowej & 5865 & 7849 & 9532 & 10483 & 179 \\
\hline Dżibuti & 277 & 374 & 871 & 3943 & 1423 \\
\hline Ghana & 5347 & 10922 & 13465 & 13411 & 251 \\
\hline $\begin{array}{l}\text { Zjednoczona Republika } \\
\text { Tanzanii }\end{array}$ & 3287 & 7874 & 10789 & 9452 & 288 \\
\hline Senegal & 3498 & 4782 & 5595 & 8143 & 233 \\
\hline Niger & 943 & 2476 & 1976 & 2299 & 244 \\
\hline Benin & 1018 & 2054 & 2561 & 4116 & 404 \\
\hline Uganda & 2054 & 4664 & 5528 & 7518 & 366 \\
\hline Burkina Faso & 1260 & 2048 & 3080 & 5230 & 415 \\
\hline Gwinea & 820 & 1405 & 2192 & 3497 & 426 \\
\hline Kenia & 5846 & 12093 & 16093 & 17655 & 302 \\
\hline Nigeria & 20754 & 44235 & 44700 & 55257 & 266 \\
\hline $\begin{array}{l}\text { Demokratyczna Republika } \\
\text { Konga }\end{array}$ & 2690 & 4500 & 6300 & 6200 & 230 \\
\hline Mozambik & 2408 & 4600 & 8334 & 7653 & 318 \\
\hline
\end{tabular}

Źródło: opracowanie własne na podstawie UNCTAD 2020 b.

Począwszy od 2015 r., wartość eksportu Polski do krajów ASS i procentowy udział tej części świata w polskim eksporcie ogółem pozostają na tym samym poziomie. Nie można zatem mówić o wzroście zaangażowania polskich producentów w tej części świata (Tabela 7).

Kolejnym czynnikiem, który istotnie wpływa na możliwości eksportowe do najszybciej rozwijających się krajów ASS, jest rosnąca z roku na rok liczba ludności (United Nation 2019). Wskaźnik dzietności utrzymuje się powyżej średniej światowej, a średnia wieku ludności w 40\% krajów regionu nie przekracza 15 lat. Najbardziej zaludnionym spośród najszybciej rozwijających się krajów regionu jest Nigeria (Tabela 5). Dla porównania - dynamika zmian liczby ludności w tym samym czasie w przypadku głównych odbiorców polskiego eksportu wyniosła: Niemcy - 102\%, Wielka Brytania - 112\% i Czechy - 104\%, co tym bardziej powinno skłaniać polskich producentów do ekspansji na rynki AS. 
Tabela 5. Liczba mieszkańców i dynamika zmian (2019 w porównaniu z 2005) w najszybciej rozwijających się krajach Afryki Subsaharyjskiej (w mln osób)

\begin{tabular}{|c|c|c|c|c|c|}
\hline Kraj & 2005 & 2010 & 2015 & 2019 & $\begin{array}{c}2005=100 \\
(\% \text { w } 2019 \\
\text { względem 2005) }\end{array}$ \\
\hline Świat & 6143494 & 6541907 & 6956824 & 7713468 & 126 \\
\hline Afryka & 810097 & 915185 & 1038265 & 1306909 & 161 \\
\hline ASS & 632575 & 721227 & 825816 & 1065128 & 168 \\
\hline Etiopia & 76346 & 87640 & 100835 & 112079 & 147 \\
\hline Rwanda & 8840 & 10039 & 11369 & 12627 & 143 \\
\hline Wybrzeże Kości Słoniowej & 18355 & 20533 & 23226 & 25717 & 140 \\
\hline Dżibuti & - & - & - & 0974 & brak danych \\
\hline Ghana & 21815 & 24780 & 27849 & 30418 & 140 \\
\hline \begin{tabular}{|l|} 
Zjednoczona Republika \\
Tanzanii \\
\end{tabular} & 38450 & 44347 & 51483 & 58005 & 151 \\
\hline Senegal & 11090 & 12678 & 14578 & 16296 & 147 \\
\hline Niger & 13624 & 16464 & 20002 & 23311 & 171 \\
\hline Benin & 7982 & 9199 & 10576 & 11801 & 148 \\
\hline Uganda & 27685 & 32428 & 38225 & 44270 & 160 \\
\hline Burkina Faso & 13422 & 15605 & 18111 & 20321 & 151 \\
\hline Gwinea & 9110 & 10192 & 11432 & 12771 & 140 \\
\hline Kenia & 36625 & 42031 & 47878 & 52574 & 144 \\
\hline Nigeria & 138865 & 158503 & 181137 & 200964 & 145 \\
\hline $\begin{array}{l}\text { Demokratyczna Republika } \\
\text { Konga }\end{array}$ & 3623 & 4274 & 4856 & 5381 & 149 \\
\hline Mozambik & 20494 & 23532 & 27042 & 30366 & 148 \\
\hline
\end{tabular}

Źródło: opracowanie własne na podstawie UNCTAD 2020d.

W większości krajów ASS najszybciej rośnie liczba ludności w wieku produkcyjnym (25-64 lat), co jest determinantą dalszego przyspieszonego wzrostu gospodarczego, tzw. „dywidendy demograficznej”. Przewiduje się, że wzrost liczby ludności w tej grupie wiekowej wyniesie od 35\% w 2019 r. do $43 \%$ w 2050 r. i 50\% w 2100 r. (United Nation 2019, s. 14). Młoda populacja ASS stwarza wiele możliwości dla krajów europejskich, zarówno w kontekście ograniczonych zasobów pracy, jak i inwestycji zagranicznych oraz możliwości eksportowych (Szukalski 2013). Boomowi demograficznemu w regionie ASS towarzyszyć będzie proces urbanizacji, wzrośnie popyt na produkty i usługi konsumpcyjne, tj. żywność, wyposażenie, farmaceutyki, usługi budowlane i opiekę zdrowotną.

Tym, co przyciąga do Afryki Subsaharyjskiej inwestorów oraz eksporterów, są głównie surowce i minerały (Bank Światowy 2019), w tym złoża złota (główny surowiec wydobywczy Afryki - $40 \%$ światowych rezerw), chromu i platyny (ponad 80\% światowych rezerw), boksytu, kobaltu, diamentów przemysłowych, fosforytu, platyny i jej metali pochodnych, wermikulitu, cyrkonu i uranu oraz paliw kopalnych i ropy naftowej. Mocną stroną regionu są zasoby surowców 
energetycznych - ropy naftowej i gazu ziemnego (ponad 10\% światowych rezerw), których głównym producentem i eksporterem jest Nigeria (12 pozycja na świecie, a w przypadku gazu ziemnego - 17 pozycja). Najważniejszymi producentami złota są Ghana (6 pozycja), Burkina Faso i Gwinea (17 pozycja). W ASS znajduje się również $6000 \mathrm{mln}$ hektarów nienaruszonej ziemi uprawnej (Milczarek 2014), co gwarantuje dalszy rozwój rolnictwa, a co za tym idzie - wzrost zapotrzebowania na maszyny i urządzenia.

Kontynuując analizę ASS jako perspektywicznego kierunku ekspansji polskich przedsiębiorstw, należy zwrócić uwagę na trudności, jakie mogą napotkać eksporterzy. Pierwszą z nich jest różnorodność językowa. W całej Afryce używanych jest ponad 2 tys. języków i dialektów (Wójtowicz, Posthumus 2016, s. 25). Ludność kontynentu na co dzień posługuje się językami etnicznymi i plemiennymi, jednak wiele krajów zachowało dawne języki kolonialne jako urzędowe (Pereltsvaig 2011), głównie francuski, angielski i portugalski, co znacznie ułatwia kontakty biznesowe i transakcje handlowe (Tabela 6).

Tabela 6. Języki urzędowe w wybranych krajach Afryki Subsaharyjskiej

\begin{tabular}{|c|l|}
\hline Język & \multicolumn{1}{|c|}{ Kraj } \\
\hline francuski & $\begin{array}{l}\text { Rwanda, Wybrzeże Kości Słoniowej, Dżibuti, Senegal, Niger, Benin, Burkina Faso, } \\
\text { Gwinea, Demokratyczna Republika Konga }\end{array}$ \\
\hline angielski & $\begin{array}{l}\text { Etiopia (angielski - główny język obcy nauczany w szkołach, amharski - urzędo- } \\
\text { wy), Rwanda, Ghana, Zjednoczona Republika Tanzanii, Uganda, Kenia, Nigeria }\end{array}$ \\
\hline portugalski & Mozambik \\
\hline
\end{tabular}

Źródło: opracowanie własne na podstawie Official and spoken languages of African countries, http://www.afrikanheritage.com/official-and-spoken-languages-of-african-countries

Przechodząc do słabych stron regionu, należy zauważyć, że czynnikiem ograniczającym możliwości eksportowe do krajów ASS jest wysoki poziom ubóstwa. Mimo szybkiego tempa wzrostu gospodarczego i rosnącego z roku na rok PKB per capita, Afryka Subsaharyjska pozostaje najbiedniejszym regionem świata (Kaczmarek 2017, s. 119-120; Bank Światowy 2020). W ubóstwie, tj. za mniej niż 1,25 USD dziennie, żyje tu ponad 50\% społeczeństwa, a w 15 krajach 20-50\% społeczeństwa żyje poniżej 1-dolarowego progu ubóstwa. W Demokratycznej Republice Konga liczba ludności żyjąca w skrajnym ubóstwie przekracza 80\% (Rynarzewski i in. 2017, s. 59). Prawie połowa ubogich ludzi w Afryce Subsaharyjskiej żyje w czterech najszybciej rozwijających się krajach regionu: Nigerii (79 mln - 20\% ogółu ubogich w regionie), Demokratycznej Republice Konga (60 mln), Tanzanii (28 mln) i Etiopii (26 mln) (Bank Światowy 2020). Z Raportu Accelerating Poverty Reduction in Africa wynika, że światowe ubóstwo będzie coraz bardziej ,afrykańskie” i zwiększy się o 90\% w 2030 r. (Beegle, Christiaensen 2019). W ramach walki z ubóstwem najbogatsze kraje regionu, w tym Nigeria i Uganda, począwszy od 2008 r., opracowują z pomocą ONZ strategię, której 
celem jest wykorzystanie globalnego popytu na naturalne produkty rolne, tj. kakao i kawę. Podstawą tej strategii jest stworzenie infrastruktury umożliwiającej przetwórstwo i magazynowanie produktów spożywczych. Z punktu widzenia polskich producentów jest to istotne, ponieważ infrastruktura tego typu przekłada się na większe możliwości eksportowe do krajów ASS.

Kolejną słabą stroną regionu - mimo że funkcjonuje w nim wiele portów - jest niezbyt dobrze rozwinięta infrastruktura transportowa, która może zwiększyć koszty obsługi transakcji handlowej o 30-40\%. Gęstość dróg na całym kontynencie wynosi $89 \mathrm{~km}$ na $1000 \mathrm{~km}^{2}$ powierzchni (to mniej niż jedna trzecia średniej światowej), a drogi utwardzone stanowią mniej niż 20\% wszystkich dróg na kontynencie. Słabo rozwinięta sieć dróg oraz linii kolejowych wraz z wysokimi kosztami transportu są istotnym utrudnieniem w transakcjach handlowych, dlatego w ciągu ostatnich dwóch dekad w Afryce Subsaharyjskiej prowadzonych jest wiele dużych projektów infrastrukturalnych.

Problemem bezpośrednio związanym z transportem towarów jest również bezpieczeństwo, a raczej jego brak - powszechne są napady na ciężarówki i kradzieże towaru. Kenia, Uganda i Rwanda podpisały porozumienie, na mocy którego opracowano system Regional Electronic Cargo Tracking (RECT). Umożliwia on lokalizowanie ciężarówek w terenie w czasie rzeczywistym w celu identyfikowania zagrożeń dla bezpieczeństwa transportu. Dodatkowym utrudnieniem są podwójne kontrole dokumentów na przejściach granicznych oraz skomplikowane i mało przejrzyste procedury.

ASS boryka się także z problemem ograniczonego dostępu do elektryczności, do której dostęp ma 44\% populacji, oraz z przerwami w dostawach energii, co również może negatywnie wpływać na prowadzenie działalności gospodarczej w niektórych krajach regionu (UNEP 2017). Ponadto dostęp do internetu w krajach ASS jest tak drogi (Alliance for Affordable Internet 2020) ${ }^{6}$, że jedynie $10 \%$ społeczeństwa może sobie pozwolić na korzystanie z sieci. Mimo to z roku na rok w szybkim tempie rośnie liczba telefonów komórkowych. Niepokoić może jednak fakt, że władze coraz częściej wykorzystują internet w walce z wewnętrznymi problemami, odłączając od niego obywateli i przedsiębiorstwa. W 2018 r. odnotowano 17 takich przypadków, a w 2019 r. co najmniej 25. W dodatku wzrasta nie tylko liczba incydentów, lecz również liczba krajów, które wyłączają internet. Należą do nich Demokratyczna Republika Konga, Etiopia i Benin (KeepItOn 2019).

Ograniczeniem w eksporcie do krajów subsaharyjskich jest także niestabilność polityczna, do której przyczyniły się głównie kolonializm (uwarunkował on

${ }^{6} \mathrm{~W}$ niektórych krajach Afryki na 1 GB danych w sieci mobilnej trzeba przeznaczyć ponad 20\% wynagrodzenia. Rwanda, która wdraża strategię krajowego dostępu szerokopasmowego, odnotowała 20-procentowy spadek ceny za 1 GB w stosunku do 2015 r. - z 20,2\% do 3,39\% średniego miesięcznego wynagrodzenia, osiągając szybsze postępy niż pozostałe kraje regionu. 
współczesną mapę geopolityczną kontynentu afrykańskiego) (Bakalarska i in. 2018; Ambukita 2016) oraz czynniki ekonomiczne, w tym zasoby naturalne i ziemia. Demokratyczna Republika Konga, określana mianem afrykańskiej Golgoty, od lat zmaga się z konfliktami o występujące na jej terenie rudy i minerały (Szukalski 2013, s. 244-266; Piórek 2017) oraz rzadkie surowce takie, jak koltan i kasyteryt, które wykorzystywane są do budowy silników rakietowych czy poszyć promów kosmicznych oraz do produkcji elektroniki (smartfonów, laptopów, konsoli do gier komputerowych) i płyt głównych urządzeń mobilnych. Handel metalami szlachetnymi przynosi zorganizowanym grupom przestępczym ogromne zyski, które wydawane są głównie na broń i łapówki - korupcja pochłania blisko 25\% PKB krajów subsaharyjskich (Kłosowicz 2017, s. 311-323). Powszechną jej formą są łapówki dla urzędników w celu uzyskania pozwolenia na budowę lub licencji na prowadzenie przedsiębiorstwa (Kaczmarek 2017, s. 147-148). Według danych publikowanych przez Transparency International średnia CPI dla Afryki Subsaharyjskiej wynosi 32 (Transparency International 2019) ${ }^{7}$.

$\mathrm{Z}$ analizy wynika, że wybrane kraje ASS są atrakcyjnym kierunkiem eksportu, jednak potencjalni eksporterzy muszą się liczyć z utrudnieniami typowymi dla rynków rozwijających się: wysokim poziomem ubóstwa, słabo rozwiniętą infrastrukturą, niestabilnością polityczną oraz korupcją. Głównym motorem dalszego wzrostu gospodarek ASS mają być postęp technologiczny i zaangażowanie w prace naukowo-badawczo-rozwojowe, w tym opracowanie „zielonej technologii" produkcji, oraz $\mathrm{w}$ dywersyfikację produkcji przemysłowej i produkcji rolnej, co wraz z niewykorzystanym do tej pory potencjałem kapitału ludzkiego oraz zasobów naturalnych ma uczynić z tego regionu gracza liczącego się na arenie międzynarodowej. Aby tak się stało, rządy krajów subsaharyjskich podejmują działania mające na celu rozwój technologii telekomunikacyjnej, lokalnego przemysłu wydobywczego oraz infrastruktury transportowej, a także oferują szereg zachęt podatkowych dla inwestorów i dostawców. Z przeprowadzonej analizy wynika, że do rynków szczególnie perspektywicznych dla polskich przedsiębiorstw planujących ekspansję w wyniku eksportu należy zaliczyć: Etiopię, Rwandę, Wybrzeże Kości Słoniowej, Ghanę, Zjednoczoną Republikę Tanzanii, Senegal, Niger, Ugandę, Kenię i Nigerię.

\footnotetext{
${ }^{7}$ Opracowany przez Transparency International indeks percepcji korupcji (CPI) określa poziom skorumpowania poszczególnych krajów oraz regionów. W badaniu, uwzględniającym 180 krajów i terytoriów, przydziela się punkty od 0 (terytorium wysoce skorumpowane) do 100 (terytorium czyste, nieskorumpowane).
} 


\section{Aktywność polskich przedsiębiorstw na rynkach Afryki Subsaharyjskiej}

Podstawą możliwości eksportowych Polski na rynki krajów ASS jest szybkie tempo wzrostu gospodarczego oraz prognozy dotyczące rozwoju społecznego w najbliższych latach. Czynnikiem wpływającym na możliwości rozwoju eksportu są również kontakty i relacje gospodarcze, które Polska przez lata wypracowywała w regionie ASS - w latach 60. i 70. XX w. zapoczątkowała współpracę z Kenią, Angolą, Mozambikiem, Zambią i Zimbabwe, otworzyła uczelnie dla studentów, organizowała misje zagraniczne, udzielała pożyczek na realizację programów rozwojowych, powołała Forum Kenijsko-Polskie i Stowarzyszenie Polaków w Zimbabwe. W ostatnim czasie Kenia stała się również popularną destynacją wśród polskich turystów (Munyama, Kowalewska 2014, s. 173-191). Od lat 80. XX w. Polska brała udział w pomocy humanitarnej i walce z głodem w Etiopii, wspierała wdrażanie projektu ekohydrologicznego i finansowała naukę. Z roku na rok rozwija się współpraca z Nigerią i Ugandą, gdzie Polska angażuje się w przemysł wydobywczy, energetyczny i teleinformatyczny (Munyama, Kowalewska 2014, s. 173-191).

Analizując aktywność konkretnych polskich przedsiębiorstw w krajach Afryki Subsaharyjskiej, należy zwrócić uwagę na przemysł maszynowy - Ursus realizuje projekt montażu ciągników rolniczych w Etiopii i Tanzanii, Lubawa SA dostarcza sprzęt dla policji w Nigerii, Asseco - liczniki energetyczne w Etiopii, Wielto - przyczepy na Wybrzeże Kości Słoniowej, Faspol - urządzenia dla mleczarstwa w Kenii, a Ferrum sprzedaje i montuje silosy w Tanzanii. Przykładem aktywności polskich przedsiębiorstw w branży wydobywczej są Grupa Azoty, która zainwestowała w kopalnię fosforytów w Senegalu, oraz holding Kulczyk Investments inwestujący w wydobycie ropy naftowej w Nigerii, węgla w Mozambiku, a także rudy żelaza w Demokratycznej Republice Konga. Polskie przedsiębiorstwa aktywnie działają również w branży farmaceutycznej (spółka Mabion) i w branży spożywczej (grupa Mokate) ${ }^{8}$.

Jednak, mimo że począwszy od 2009 r., Polska odnotowuje dodatnie saldo w bilansie obrotów towarowych z krajami Afryki (UNCTAD 2020c), kraje ASS pozostają na marginesie polskiego eksportu (Osiecki 2018).

W latach 2005-2019 wartość eksportu Polski do krajów Afryki Subsaharyjskiej wzrosła ponad czterokrotnie (Tabela 7), a od 2014 r. utrzymuje się na niezmienionym poziomie - udział krajów ASS w polskim eksporcie oscylował między 0,5-0,7\%. Mimo promowania Afryki jako perspektywicznego rynku i oferowanego od 2013 r. przez polski rząd wsparcia w ramach programu

${ }^{8}$ Opracowane na podstawie informacji zawartych na stronach internetowych wymienionych przedsiębiorstw. 
GoAfrica, eksport Polski do krajów ASS nie zmienia się istotnie. Jeśli chodzi o kraje o najszybszym tempie wzrostu gospodarczego, które odnotowywały największy udział w polskim eksporcie, to były to Nigeria, Senegal, Ghana i Kenia (Tabela 7), a w skali świata - Etiopia i Rwanda (ich udział zmniejsza się jednak $\mathrm{z}$ roku na rok).

Tabela 7. Wartość polskiego eksportu na rynki wybranych krajów Afryki Subsaharyjskiej oraz ich udział procentowy w polskim eksporcie ogółem (lata 2005-2019, w mln USD)

\begin{tabular}{|c|c|c|c|c|c|c|c|c|}
\hline \multirow{2}{*}{ Region/kraj } & \multicolumn{2}{|c|}{2005} & \multicolumn{2}{|c|}{2010} & \multicolumn{2}{|c|}{2015} & \multicolumn{2}{|c|}{2019} \\
\hline & wartość & udzial & wartość & udzial & wartość & udzial & wartość & udzial \\
\hline Afryka & 771,2 & 0,9 & 1784,3 & 1,1 & 2844,3 & 1,5 & 3079,4 & 1,2 \\
\hline ASS & 371,1 & 0,4 & 1074,7 & 0,7 & 1604,3 & $\mathbf{0 , 8}$ & 1691,4 & 0,7 \\
\hline Etiopia & 3,9 & 0,004 & 5,3 & 0,003 & 52,9 & 0,03 & 15,3 & 0,006 \\
\hline Rwanda & 0,1 & - & 23,9 & 0,01 & 1,7 & - & 1,1 & - \\
\hline $\begin{array}{l}\text { Wybrzeże } \\
\text { Kości } \\
\text { Słoniowej }\end{array}$ & 11,9 & 0,01 & 26,8 & 0,02 & 17,9 & 0,01 & 37,5 & 0,01 \\
\hline Ghana & 14,8 & 0,02 & 28,5 & 0,02 & 36,0 & 0,02 & 69,0 & 0,03 \\
\hline $\begin{array}{l}\text { Zjednoczona } \\
\text { Republika } \\
\text { Tanzanii } \\
\end{array}$ & 1,4 & - & 9,4 & - & 24,9 & 0,01 & 26,7 & 0,01 \\
\hline Senegal & 6,2 & - & 14,3 & 0,01 & 43,6 & 0,02 & 102,2 & 0,04 \\
\hline Niger & 1,1 & - & 2,6 & - & 3,3 & - & 9,1 & - \\
\hline Uganda & 2,2 & - & 18,8 & - & 36,2 & 0,02 & 13,6 & - \\
\hline Kenia & 4,4 & - & 25,4 & 0,02 & 78,4 & 0,04 & 54,6 & 0,02 \\
\hline Nigeria & 44,3 & 0,05 & 72,5 & 0,05 & 117,8 & 0,06 & 122,7 & 0,05 \\
\hline Świat & 89378,1 & 100,0 & 157065,0 & 100,0 & 194461,2 & 100,0 & 251864,8 & 100,0 \\
\hline
\end{tabular}

Źródło: opracowanie własne na podstawie UNCTAD 2020c.

W opinii ekspertów możliwe jest zwiększenie udziału krajów ASS w polskim eksporcie do poziomu 3\%. Perspektywicznymi rynkami są Kenia, Nigeria, Senegal i WKS, a do obiecujących sektorów należą: budowlany, wykończeń i wyposażeń wnętrz, farmaceutyczny, medyczny, telemedycyna, kosmetyczny, rolno-spożywczy oraz maszynowy, w tym części, podzespoły i akcesoria dla branży automotive (PAIiH 2020).

Ze względu na swoją lokalizację Kenia postrzegana jest jako „gospodarcza brama" do Afryki Wschodniej. Stabilne tempo wzrostu gospodarczego i ożywienie w kenijskim sektorze budowlanym mogą być szansą dla polskich inwestorów oraz dostawców usług i materiałów budowlanych, wyposażenia i wykończenia wnętrz, stolarki okiennej i drzwiowej, armatury łazienkowej, mebli, wykładzin i dywanów. Ostatnio wzrosło zapotrzebowanie na sprzęt do testowania laboratoryjnego oraz maski ochronne, co może być okazją dla polskich dostawców sprzętu medycznego. 
Nigeria skupia się na lokalnej produkcji i przetwórstwie. Daje to polskim przedsiębiorstwom możliwości inwestycyjne oraz szanse na współpracę w zakresie technologii i know-how w wielu sektorach. Duży i chłonny rynek nigeryjski, od podstaw rozwijający infrastrukturę produkcyjną, stwarza wiele możliwości dla branż budowlanej i maszynowej, w tym producentów i dostawców maszyn rolniczych, budowlanych, części samochodowych, oraz dla branży IT - dostawców sprzętu telekomunikacyjnego i oprogramowania.

Priorytetem Senegalu jest zapewnienie samowystarczalności w sektorze zdrowia i żywności. Uzależnienie kraju od importu sprzętu, aparatury medycznej i leków, zwłaszcza w trakcie pandemii koronawirusa, przyczyniło się do opracowania strategii na rzecz rozwoju sektora opieki zdrowotnej. Daje to pole do działania polskim producentom i eksporterom sprzętu medycznego, jego podzespołów, technologii do utylizacji odpadów, badań laboratoryjnych, producentom leków i artykułów opatrunkowych, a także dostawcom i wykonawcom centrów medycznych. Urodzajne gleby i odpowiednie warunki klimatyczne Senegalu sprzyjają produkcji żywności, problemem jest jednak brak infrastruktury pozwalającej na jej przetwórstwo i magazynowanie. Sytuację tę mogą wykorzystać polscy producenci systemów nawadniania pól, oczyszczania wody oraz przetwórstwa żywności i mleka. Niski poziom uprzemysłowienia gospodarki Senegalu stwarza zapotrzebowanie na dostawy dla branż: budowlanej, wykończenia mieszkań, samochodowej i telekomunikacyjnej.

Z kolei Wybrzeże Kości Słoniowej może umożliwić rozwój działalności dostawcom: materiałów i sprzętu medycznego, sprzętu budowlanego i materiałów wykończeniowych, technologii oraz sprzętu do rozbudowy infrastruktury przetwórczej i magazynowej dla przemysłu rolno-spożywczego (PAIiH 2020).

Stanowisko polskiego rządu dotyczące perspektywicznych branż eksportujących na rynki krajów Afryki Subsaharyjskiej znajduje potwierdzenie w ocenie możliwości rozwoju eksportu Polski do krajów Afryki (Knap 2016, s. 236-251), która wykazała, że w grupie 20 towarów o największym potencjale eksportowym większość stanowią maszyny, urządzenia oraz sprzęt transportowy, produkty przemysłowe powstałe na skutek przetworzenia surowców, artykuły przemysłowe, w tym meble i ich części, chemikalia, paliwa mineralne i smary oraz żywność (Knap 2016, s. 236-251). Trwający w państwach ASS boom technologiczny sprawia, że rośnie popyt na sprzęt IT, tj. telefony komórkowe i wyposażenie biurowe (Bonikowska 2016).

W przypadku analizowanych krajów polskim eksporterom sprzyjają wysoka jakość oferowanych produktów oraz ich stosunkowo niska cena. Nie bez znaczenia jest także fakt, że Polska jako państwo nigdy nie posiadała kolonii (może dlatego nadal jest ,wielkim nieobecnym” w rozgrywkach gospodarczych na rynkach Czarnego Lądu), dzięki czemu polscy przedsiębiorcy budzą zaufanie wśród 
afrykańskich kontrahentów, co jest istotnym warunkiem powodzenia w negocjacjach, a później - w wywiązywaniu się z kontraktu handlowego.

Jak w związku z tym wykorzystać potencjał handlowy krajów Afryki Subsaharyjskiej i jakie czynniki powinni brać pod uwagę polscy eksporterzy towarów na rynki Afryki Subsaharyjskiej?

\section{Wskazówki dla przedsiębiorstw planujących ekspansję poprzez eksport}

Omówione we wcześniejszej części artykułu uwarunkowania makroekonomiczne mogą przyczynić się do sukcesu przedsiębiorstw eksportujących na rynki ASS, jednak warto poruszyć również kilka istotnych kwestii dotyczących odpowiedniego przygotowania tych przedsiębiorstw. Są to:

1. prawidłowo przygotowana strategia marketingowa uwzględniająca różnice kulturowe;

2. właściwie przeprowadzony proces nawiązywania kontaktów i budowania relacji biznesowych;

3. minimalizacja ryzyka związanego z transakcją;

4. odpowiednie przygotowanie procesu transportowego;

5. możliwość uzyskania wsparcia od instytucji rządowych oraz instytucji otoczenia biznesu.

Pierwszym z warunków, który powinno spełnić przedsiębiorstwo planujące eksport na rynki afrykańskie, jest przygotowanie prawidłowej strategii marketingowej, w tym strategii sprzedaży. Na rynku międzynarodowym funkcjonują cztery podstawowe modele strategii marketingowych (Rymarczyk 1996, s. 75):

1. Strategia etnocentryczna: eksport na rynki podobne do rynku krajowego - w tym przypadku strategia marketingowa może być tożsama $\mathrm{z}$ realizowaną na rynku krajowym.

2. Strategia policentryczna: dostosowanie działań i oferty przedsiębiorstwa do wymagań rynku różniącego się od rynku krajowego eksportera.

3. Strategia globalna: traktowanie wszystkich rynków jako jednolitego ryn$\mathrm{ku}$, pomimo występowania między nimi różnic. Zgodnie $\mathrm{z}$ tą strategią ignoruje się specyfikę poszczególnych rynków, a co za tym idzie - nie tworzy się odrębnych strategii dla poszczególnych rynków.

4. Strategia dualna: dążenie do połączenia korzyści płynącej z globalnej integracji z próbą dostosowania się do warunków panujących na lokalnym rynku. 
W przypadku rynków różniących się od rodzimego rynku eksportera uwarunkowaniami społecznymi, kulturowymi, ekonomicznymi i jednocześnie w sytuacji, w której eksporter nie ma silnej, rozpoznawalnej globalnie marki - a więc w sytuacji, w jakiej znajduje się większość polskich eksporterów - zaleca się strategię policentryczną bądź dualną. Oznacza to, że polskie przedsiębiorstwa powinny rozpoczynać proces eksportu na rynki ASS od przygotowania strategii marketingowej dostosowanej do rynku docelowego.

Strategia w marketingu międzynarodowym jest zagadnieniem szerokim, którego omówienie wykracza poza ramy tego artykułu, niemniej jednak warto zwrócić uwagę na trzy istotne kwestie praktyczne związane z jej przygotowaniem:

1. Konieczność przeanalizowania rynku docelowego w wymiarze makroekonomicznym oraz w wymiarze otoczenia konkurencyjnego.

2. Konieczność przygotowania podstawowych założeń strategii marketingowej w oparciu o marketing mix 4P, 5P lub inny przyjęty do prac nad strategią.

3. Dogłębne zrozumienie różnic kulturowych determinujących zachowania konsumentów oraz relacje biznesowe na rynkach docelowych.

Już pierwsza kwestia niejednokrotnie sprawia przedsiębiorcom trudności. Zgodnie z przywoływanym przez Polską Agencję Rozwoju Przedsiębiorczości badaniem z 2014 r. (Bąk 2014, s. 11), aż 78,6\% badanych przedsiębiorstw wskazuje na brak dostępu do informacji o rynkach eksportowych, a $84,6 \%$ wskazuje na ograniczoną ilość i niską jakość informacji o rynkach zbytu jako jedną z głównych barier ekspansji zagranicznej. Sytuacja jest szczególnie trudna w przypadku rynków afrykańskich, które analizowane są znacznie rzadziej niż wiodące gospodarki światowe i nie są tak dokładnie opisane. Najważniejsze dane makroekonomiczne są względnie łatwo dostępne, jednak szczegółowe analizy branżowe, niezbędne do oszacowania popytu oraz analizowania konkurencji, są niekiedy nieosiągalne. Poszukując danych wyjściowych do analizy rynku Afryki Subsaharyjskiej, przedsiębiorcy powinni pamiętać, że mogą uzyskać informacje od ambasad, Polskiej Agencji Inwestycji i Handlu, Polsko-Afrykańskiej Izby Przemysłowo-Handlowej, z raportów przygotowywanych przez KUKE oraz banki, a także od komercyjnych wywiadowni gospodarczych i przedsiębiorstw doradczych specjalizujących się we wspieraniu eksporterów w działalności na konkretnych rynkach.

Płynące $\mathrm{z}$ analizy rynku informacje powinny stać się podstawą strategii marketingowej dostosowanej do danego rynku. Jak już wspomniano, dyskusja nad istotą strategii marketingowych przekroczyłaby znacząco ramy niniejszego artykułu, dlatego zostanie ona zawężona do jednej kwestii - konieczności uwzględnienia specyfiki rynku w planowaniu marketingu mix. Tradycyjny, podstawowy marketing mix 4P obejmuje cztery podstawowe obszary (Needham 1996, s. 28): produkt (product), cenę (price), dystrybucję (place) i promocję (promotion). Już 
w przypadku samego produktu widoczne są elementy, które powinny zostać dostosowane do potrzeb afrykańskiego rynku. Mogą to być fizyczne, użytkowe cechy produktów, związane choćby z koniecznością przystosowania ich do funkcjonowania $\mathrm{w}$ odmiennym klimacie oraz $\mathrm{w}$ innych warunkach społecznych i gospodarczych. Adaptacja produktów często odnosi się również do takich kwestii jak dostępność pełnej linii produktowej, zarządzanie cyklem życia produktu czy chociażby do kwestii opakowania. W przypadku rynków ASS istotnym elementem wymagającym odrębnej strategii jest także cena. $Z$ jednej strony marża powinna uzasadniać ponoszone ryzyko oraz uwzględniać koszty transakcji eksportowych, a drugiej strony cena produktu powinna być adekwatna do możliwości lokalnego rynku. Pisząc o możliwościach lokalnego rynku, należy zwrócić uwagę na ogromne zróżnicowanie Afryki Subsaharyjskiej - często nawet w obrębie jednego państwa występują istotne różnice w poziomie zamożności. W Afryce są rejony bardzo ubogie, ale jednocześnie poziom życia mieszkańców dużych metropolii nie odbiega wiele od poziomu życia $w$ innych częściach świata. Obrana polityka cenowa musi zatem odzwierciedlać możliwości grupy docelowej oraz być powiązana z popytem na tym obszarze, na którym produkt będzie dystrybuowany. Dystrybucja produktu powinna uwzględniać zarówno wspomniane już zróżnicowanie geograficzne popytu, jak i możliwości zaopatrzenia poszczególnych regionów kontynentu, którego sieć transportowa i zaplecze logistyczne nie są zbyt dobrze rozwinięte, a ryzyko związane z przemieszczaniem i składowaniem towarów jest wysokie. W końcu promocja - ostatni ze składników, silnie opierający się na zrozumieniu różnic kulturowych i wymagający adaptacji całej komunikacji marketingowej do specyfiki rynku afrykańskiego. W modelach marketingu mix, w których kładzie się nacisk na czynnik ludzki, wpływ różnic kulturowych jest jeszcze bardziej widoczny. Przyglądając się, nawet pobieżnie, elementom marketingu mix, można zauważyć, że powinny być one determinowane przez dwie podstawowe kwestie - panujące na danym rynku warunki makroekonomiczne i charakterystykę otoczenia konkurencyjnego oraz właśnie różnice kulturowe.

Punktem wyjścia do określenia najważniejszych różnic kulturowych, których zrozumienie pozwoli na stworzenie skutecznej strategii działania na rynku afrykańskim, mogą być badania prowadzone przez prof. G. Hofstede (Hofstede 2020). Analizując mapy w modelu Hofstede, można zauważyć, że różnice kulturowe między Polską a państwami Afryki Subsaharyjskiej polegają w szczególności na większym niż w Polsce kolektywizmie, na promowaniu innego zestawu wartości i podejścia do niepewności w biznesie czy też na umiejętności odraczania korzyści. Różnice kulturowe wyjaśnia również częściowo oparty na badaniach prof. Hofstede model GLOBE, rozwinięty pod kierunkiem prof. R.J. House'a $z$ Wharton School of the University of Pennsylvania (Javidan, House 2002, s. 1-2). Sam model GLOBE nawiązuje również do teorii F.R. Kluckhohn i F. Stodtbecka, H.C. Triandisa, R.G. Lorda i K.J. Maher czy F. Trompenaarsa 
i jest długookresowym projektem międzynarodowym, koordynowanym przez Thunderbird School of Global Management w USA (Komor 2010, s. 403). Do istotnych różnic kulturowych należy zaliczyć: barierę językową, wierzenia, rytuały, symbolikę i religię oraz różnice w zachowaniach zakupowych i postawach konsumenckich czy wartości wyznawane w społeczeństwach. Społeczeństwa afrykańskie mają też zupełnie inne podejście do negocjacji czy przestrzegania ustalonych harmonogramów, a także terminów płatności. Zrozumienie tych różnic i dostosowanie się do nich jest kluczowe dla odniesienia sukcesu eksportowego w państwach Afryki Subsaharyjskiej.

Drugim bardzo istotnym warunkiem skutecznej ekspansji na rynki Afryki Subsaharyjskiej jest właściwie przeprowadzony proces nawiązywania kontaktów i budowania relacji biznesowych. $Z$ jednej strony chodzi o uwzględnienie wspomnianych już różnic kulturowych, a z drugiej - o zapewnienie bezpieczeństwa na lokalnym rynku dzięki znalezieniu wiarygodnego partnera. Jeśli chodzi o pozyskiwanie partnerów na rynku afrykańskim, a następnie budowanie trwałych relacji biznesowych, to istotne jest nie tylko dotarcie do potencjalnych partnerów, lecz również ich umiejętna weryfikacja. W dotarciu do partnerów po stronie afrykańskiej pomocne mogą być wspomniane już placówki dyplomatyczne, izby handlowe, a także komercyjne przedsiębiorstwa wspierające ekspansję na rynki zagraniczne. Warto korzystać również z polskiego wsparcia rządowego, w szczególności brać udziału w misjach gospodarczych, konferencjach, seminariach i spotkaniach biznesowych (przykładem takiego wsparcia jest realizowany od 2013 r. program GoAfrica). Pomocna może być również sieć EEN ${ }^{9}$ - po nawiązaniu wstępnych relacji z partnerem po stronie afrykańskiej powinna nastąpić weryfikacja jego wiarygodności i sytuacji finansowej. Niestety określenie wiarygodności partnerów biznesowych na rynku afrykańskim wciąż jest jeszcze trudnym zadaniem. Pomocne w procesie weryfikacji wiarygodności partnerów mogą okazać się placówki dyplomatyczne i instytucje rządowe (w tym PAIH), izby przemysłowo-handlowe, lokalne zrzeszenia gospodarcze i branżowe, ale przede wszystkim - międzynarodowe wywiadownie gospodarcze, np. Bisnode, który zapewnia szybki i obiektywny raport na temat sytuacji ekonomiczno-finansowej partnera z dowolnego kraju na świecie.

Jeśli chodzi o pozyskiwanie i weryfikację kontaktów biznesowych w krajach afrykańskich, to należy też wspomnieć o roli networkingu i nawiązanych już na tym rynku relacji - zaufana osoba kontaktowa może stać się doskonałym przewodnikiem, a w przypadku kultury afrykańskiej, w której wszystkie kontrakty, sprawy biznesowe i sprawy urzędowe najłatwiej i najskuteczniej załatwia się osobiście, rola zaufanego i szanowanego na danym rynku przedstawiciela jest szczególnie istotna.

${ }_{9}$ Więcej informacji na temat działalności EEN można znaleźć pod adresem http://www.een.org.pl. 
Oprócz weryfikacji wiarygodności partnera biznesowego warunkiem skutecznej działalności eksportowej na rynkach Afryki Subsaharyjskiej jest umiejętne zabezpieczenie transakcji, mające na celu minimalizację ryzyka w projekcie eksportowym. Powinno ono obejmować weryfikację zagadnień prawnych w kontrakcie, wybór bezpiecznych dla eksportera form płatności, umiejętne zabezpieczenie przed ryzykiem kursowym oraz ubezpieczenie towaru. Jeśli chodzi o zagadnienia prawne, to pomocne w ich weryfikacji mogą się okazać wspomniane już instytucje państwowe i komercyjne. Szczegółowe omówienie form zabezpieczeń w handlu zagranicznym przekroczyłoby ramy niniejszego artykułu, niemniej jednak warto nadmienić, że eksporter powinien zapoznać się z praktycznymi aspektami wykorzystania akredytywy, inkasa dokumentowego (chociaż w przypadku inkasa istnieje ryzyko niewykupienia dokumentów przez odbiorcę - wówczas eksporter obciążony jest organizacją powrotnego transportu towaru i jego kosztami), gwarancji bankowych oraz faktoringu eksportowego. Wspominając o faktoringu eksportowym, warto podkreślić dodatkową korzyść płynącą ze współpracy z faktorem, który - będąc najczęściej dużą instytucją finansową - może również pomóc eksporterowi w organizacji procesu eksportowego, tj. weryfikacji wiarygodności kontrahenta, czy doradzić wybór odpowiedniej formy rozliczeń z importerem. Co do ryzyka kursowego, należy pamiętać, że nieumiejętnie stosowane narzędzia zarządzania ryzykiem kursowym mogą przynieść eksporterowi straty, jednak ich właściwe wykorzystanie może uchronić przedsiębiorstwo przed wydatkami związanymi z różnicami kursowymi.

Kolejnym praktycznym elementem transakcji eksportowych na rynek afrykański jest odpowiednie przygotowanie transportu. Problemy związane z transportem towarów są jednymi z najistotniejszych utrudnień dla podmiotów eksportujących na rynki afrykańskie. Na tę niekorzystną sytuację ma wpływ kilka czynników: słaba sieć drogowa i infrastruktura towarzysząca, liczne wymogi formalne i szybko zmieniające się przepisy prawne, przedłużające się ze względu na formalności oraz słabą infrastrukturę procesy transportowe, wysoki poziom korupcji oraz duże ryzyko kradzieży. W Afryce rozpoczęto wprawdzie wdrażanie inicjatyw i programów ukierunkowanych na rozwój infrastruktury transportowej (choćby przyjęty w 2017 r. wart 360 mld USD program rozwoju infrastruktury transportowej i energetycznej, realizowany przez kraje Unii Afrykańskiej, czy rozwijany przez Kenię, Ugandę i Rwandę system RECT), jednak organizacja i bezpieczeństwo transportu $\mathrm{w}$ dalszym ciągu pozostają jednymi z największych utrudnień dla eksporterów. Rozważając eksport na rynki afrykańskie, kontrakt można podpisać na warunkach bez gestii transportowej, jednak eksporter pozbawia się wówczas korzyści związanych z posiadaniem gestii. Najlepszym rozwiązaniem jest wybór spedytora o dużym i wieloletnim doświadczeniu na rynku Afryki Subsaharyjskiej, który dysponuje siecią zaufanych lokalnych agentów bądź własnych biur. Niebagatelną rolę odgrywa również ubezpieczenie towarów, 
przy czym należy pamiętać, że standardowe ubezpieczenie OC spedytora ogranicza się jedynie do sytuacji, w których spedytor nie zachował należytej staranności w realizacji zlecenia bądź w wyborze podwykonawcy. W przypadku eksportu towarów na obarczone wysokim ryzykiem rynki afrykańskie istotne jest zatem wykupienie dodatkowego ubezpieczenia cargo.

Podsumowując powyższe wskazówki, należy podkreślić istotną dla polskich eksporterów możliwość uzyskania wsparcia od instytucji rządowych oraz instytucji otoczenia biznesu. Najbardziej pomocne dla polskich podmiotów eksportujących na rynki ASS mogą być: Polsko-Afrykańska Izba Przemysłowo-Handlowa, polskie placówki dyplomatyczne w Afryce oraz afrykańskie placówki dyplomatyczne w Polsce, a także PAIiH, wraz z programem GoAfrica, oraz KUKE.

Jeśli chodzi o kwestie praktyczne ekspansji na rynki afrykańskie, to warto krótko skomentować wspomniany program GoAfrica, prowadzony przez PAIiH od 2013 r., który obejmuje wiele projektów wspierających polskich przedsiębiorców w ekspansji na rynki Afryki, zwłaszcza strefy subsaharyjskiej. Głównym założeniem programu była intensyfikacja stosunków gospodarczych między Polską i Afryką oraz otwarcie nowych rynków zbytu dla polskich przedsiębiorstw. Podstawą programu jest założenie, że pomoc polskim eksporterom powinna opierać się nie tylko na negocjowaniu porozumień na szczeblu rządowym, lecz również na bieżącym wsparciu strategicznym i operacyjnym, czyli na udzielaniu przedsiębiorcom porad, udostępnianiu im informacji i analiz czy na ułatwianiu im kontaktów z potencjalnymi partnerami biznesowymi. Głównym założeniem programu było kompleksowe wsparcie polskich przedsiębiorców w ekspansji na rynek afrykański. Cel ten ma zostać osiągnięty w wyniku udostępniania analiz i opracowań rynkowych, dzięki pomocy w zdobywaniu lokalnych kontaktów i organizowaniu misji gospodarczych, wyjazdom na targi oraz spotkaniom z potencjalnymi kontrahentami po stronie afrykańskiej, a także dzięki weryfikacji potencjalnych partnerów (Portal Promocji Eksportu 2020). W ramach programu organizowane były również warsztaty i szkolenia dla przedsiębiorców planujących ekspansję do Afryki. W ciągu pierwszych dwóch lat z programu skorzystało 3,5 tys. osób w ramach 40 imprez promocyjnych, zorganizowano 5 misji biznesowych, 7 rozpoznawczych oraz 2 imprezy targowe, a także przygotowano 11 analiz rynkowych (Bonikowska 2016). Niestety w ostatnich latach dynamika działań związanych z programem znacząco się zmniejszyła, brakuje informacji na temat programu po 2016 r. Na Portalu Promocji Eksportu nadal można znaleźć opis programu wraz z danymi kontaktowymi dla przedsiębiorstw zainteresowanych wsparciem oraz odnośnikami do grupy krajów afrykańskich i wybranymi raportami rynkowymi. Co ciekawe, dane i raporty opublikowane na stronie odnoszą się w głównej mierze do roku 2015, a najnowsze z nich zamieszczone zostały w 2018 r. Nie funkcjonuje już 
też strona internetowa programu GoAfrica. Ta sytuacja może budzić wątpliwości przedsiębiorców co do tego, czy mogą liczyć na wsparcie instytucjonalne w przypadku zainteresowania się rynkiem afrykańskim.

Kolejną słabą stroną wsparcia PAIiH jest ograniczona liczba zagranicznych biur handlowych w Afryce. Planowano otwarcie kolejnych, ale niestety biur afrykańskich jest wciąż niewiele. Siedem dotychczasowych zlokalizowanych jest w Maroku, Senegalu, na Wybrzeżu Kości Słoniowej, w Nigerii, RPA, Kenii oraz w Egipcie (PAIiH 2020).

Wspominając o wsparciu instytucjonalnym, warto poświęcić kilka zdań ofercie KUKE. Choć podstawowym obszarem działalności korporacji są gwarancje ubezpieczeniowe, ubezpieczanie kontraktów, ubezpieczanie inwestycji oraz faktoring, to jednocześnie, doceniając potencjał rozwojowy Afryki, KUKE przygotowała program wsparcia informacyjnego dla przedsiębiorstw planujących ekspansję w tym regionie. Projekt - pod nazwą Program Handlu Zagranicznego (PHZ), prowadzony wspólnie z Bankiem BGŻ PNB Paribas, Bisnode Polska oraz dziennikiem „Rzeczpospolita” - zaowocował opracowaniem materiałów, które mogą być wartościowym wsparciem dla polskich przedsiębiorstw zainteresowanych rynkiem afrykańskim (KUKE 2020). Choć podobnie jak w przypadku programu GoAfrica, strona PHZ już nie funkcjonuje, to jednak na stronie KUKE można znaleźć wiele istotnych informacji oraz uzyskać dostęp do poradników i raportów dotyczących wybranych rynków. W ramach programu w 2018 r. przygotowany został Przewodnik po rynkach afrykańskich (Bakalarska i in. 2018), zawierający informacje na temat potencjału kontynentu oraz praktyczne wskazówki dla eksporterów pozwalające zrozumieć lokalną kulturę oraz proces nawiązywania i realizacji kontaktów handlowych.

Oceniając obecne wsparcie instytucjonalne dla polskich eksporterów zainteresowanych kierunkiem afrykańskim, należy jednak pamiętać o tym, że w 2020 r. z powodu pandemii COVID-19 bezpośrednie kontakty międzynarodowe na wszystkich rynkach zostały znacząco ograniczone, dlatego wyciąganie wniosków o spowolnieniu czy zaniechaniu działań związanych z rozwojem kierunku afrykańskiego byłoby nieuprawnione. Pełna i obiektywna ocena bieżącego wsparcia dla przedsiębiorców będzie możliwa dopiero po zakończeniu pandemii i normalizacji międzynarodowej aktywności gospodarczej.

\section{Podsumowanie}

Na podstawie analiz i rekomendacji zawartych w niniejszym opracowaniu można stwierdzić, że wybrane kraje regionu Afryki Subsaharyjskiej stają się istotnym partnerem $\mathrm{w}$ transakcjach handlowych oraz inwestycjach bezpośrednich. 
Szybkie tempo wzrostu gospodarczego licznej grupy krajów tego obszaru - którego podstawą są głównie zasoby strategicznych dla wielu gospodarek świata surowców naturalnych - zaangażowanie w prace naukowo-badawcze oraz wdrażanie nowoczesnych technologii w wielu dziedzinach życia gospodarczego i społecznego sprawiają, że kraje subsaharyjskie od lat wzbudzają zainteresowanie zarówno ekonomistów, jak i przedsiębiorców. Podążając za przykładem wielu zagranicznych inwestorów i producentów, polscy przedsiębiorcy realizujący strategię internacjonalizacji powinni interesować się możliwościami eksportowymi na rynki krajów Afryki Subsaharyjskiej i próbować opracować plan ekspansji w celu wykorzystania potencjału tego regionu i budowania trwałych relacji biznesowych.

Podsumowując wskazane rekomendacje dla przedsiębiorstw planujących ekspansję na rynki Afryki Subsaharyjskiej, warto podkreślić elementy kluczowe dla powodzenia projektu eksportowego, które w przypadku współpracy z krajami afrykańskimi obarczone są również pewnym ryzykiem. Pierwszym koniecznym warunkiem powodzenia ekspansji na rynki ASS jest dokładna analiza docelowego rynku, która będzie mogła stać się podstawą dostosowanej do niego strategii marketingowej. Drugim warunkiem jest przygotowanie strategii marketingowej oraz zaplanowanie procesu eksportowego w taki sposób, aby uwzględniały one nie tylko polityczno-gospodarczą specyfikę rynku, lecz również różnice kulturowe, ponieważ to one będą miały wpływ na komunikację marki, a także na sposób nawiązania relacji, prowadzenia negocjacji, a następnie - współpracy z afrykańskimi partnerami. Trzecim warunkiem jest dotarcie do potencjalnych partnerów biznesowych, właściwa weryfikacja ich wiarygodności oraz umiejętne budowanie relacji. Ostatnim z kluczowych elementów jest zaprojektowanie i realizacja transakcji eksportowej w sposób, który pozwoli zminimalizować występujące na rynku ASS ryzyko. Na tym etapie szczególnie istotne jest zabezpieczenie zagadnień prawnych i płatności, ochrona marży przed różnicami kursowymi oraz staranne zaplanowanie procesu transportowego z pomocą spedytora mającego doświadczenie na rynku afrykańskim. Jeśli chodzi o sam proces transportu, to należy zwrócić uwagę na zabezpieczenie przewożonego towaru, minimalizowanie ryzyka opóźnień w dostawach oraz wymuszeń korupcyjnych, a także ochronę ubezpieczeniową towaru. Warto dodać, że zaufani, wiarygodni partnerzy biznesowi (zarówno odbiorca, jak i spedytor), cieszący się silną pozycją oraz uznaniem na rynku lokalnym, mogą być dla polskich eksporterów równie istotnym gwarantem bezpieczeństwa jak wsparcie instytucjonalne.

Polscy eksporterzy powinni pamiętać również o możliwości uzyskania wsparcia zarówno od instytucji rządowych oraz izb i stowarzyszeń gospodarczych, jak i od typowo komercyjnych przedsiębiorstw zapewniających pomoc w procesie eksportowym na rynek subsaharyjski. 


\section{Bibliografia}

African Development Bank Group (2020), African Economic Outlook 2020: Developing Africa's workforce for the future, https://www.afdb.org/en/documents/african-economic-outlook-2020 (data dostępu: 20.11.2020).

Alliance for Affordable Internet (2020), The Affordability Report 2020.

Ambukita E. (2016), Bezpośrednie inwestycje zagraniczne - motywy i bariery inwestowania w Afryce Subsaharyjskiej, ,Finanse, Rynki Finansowe, Ubezpieczenia", 4.

Bakalarska M., Nawrot K.A., Masłoń-Oracz A. (2018), Przewodnik po rynkach afrykańskich, BGŻ BNP Paribas, Warszawa.

Bank Światowy (2017), Global Economic Prospects, January 2017: Weak Investment in Uncertain Times, Washington, D.C., https://openknowledge. worldbank.org/handle/10986/25823 (data dostępu: 20.11.2020).

Bank Światowy (2019), Commodity Markets Outlook 2019, https://openknowledge.worldbank.org/handle/10986/32633 (data dostępu: 20.11.2020).

Bank Światowy (2019a), Global Economic Prospects, January 2019: Darkening Skies, Washington, D.C., https://openknowledge.worldbank.org/handle/10986/31066 (data dostępu: 20.11.2020).

Bank Światowy (2020), Poverty and Shared Prosperity 2020: Reversals of Fortune, Washington, D.C., https://elibrary.worldbank.org/doi/pdf/10.1596/978-14648-1602-4 (data dostępu: 20.11.2020).

Bank Światowy w Afryce (2020), https://www.worldbank.org/en/region/afr/ overview (data dostępu: 30.12.2020).

Bąk M. (2014), Marketing eksportowy-poradnik dla matych i średnich przedsiębiorców, Wydawnictwo Polskiej Agencji Rozwoju Przedsiębiorczości, Warszawa.

Beegle K., Christiaensen L. (2019), Accelerating Poverty Reduction in Africa, Washington, D.C., World Bank, https://openknowledge.worldbank.org/handle/10986/32354 (data dostępu: 30.11.2020).

Bonikowska M. (2016), „Go Africa”: co dalej?, Centrum Stosunków Międzynarodowych, https://csm.org.pl/wp-content/uploads/2016/03/CSM-Analiza-Bonikowska-AFRYKA-21.03.2016.pdf (data dostępu: 15.09.2020).

Cieślik E., Czernichowski K., Ndiaye B. (2020), Afryka Subsaharyjska. Potencjat, problemy i możliwości dla Polski, Wydawnictwo Naukowe PWN, Warszawa.

Costa R. (2020), Global trading blocs through the lens of ICP 2017 results, https://blogs.worldbank.org/opendata/global-trading-blocs-through-lens-icp-2017-results (data dostępu: 23.11.2020).

Gostomski E., Michałowski T. (2018), Ekspansja inwestycyjna Chin w Afryce, „Pieniądze i Więź”, 2(79). 
GUS (2019), Rocznik Statystyki Międzynarodowej 2019.

Hofstede G. (2020), The 6-D model of national culture, http://www.geerthofstede. com (data dostępu: 24.09.2020).

Javidan M., House R.J. (2002), Leadership and Cultures Around the World: Findings from GLOBE: An introduction to the special issue, „Journal of World Business", 37.

Kaczmarek F. (2017), Dylematy polityki rozwojowej Unii Europejskiej wobec Afryki Subsaharyjskiej w latach 2000-2015, Wydawnictwo Uniwersytetu Ekonomicznego w Poznaniu, Poznań.

KeepItOn (2019), Targeted, cut off, and left in the dark. The \#KeepItOn report on internet shutdowns in 2019, http://www.accessnow.org/cms/assets/ uploads/2020/02/KeepItOn-2019-report-1.pdf (data dostępu: 20.11.2020).

Kłosowicz R. (2017), Konteksty dysfunkcyjności państw Afryki Subsaharyjskiej, Wydawnictwo Uniwersytetu Jagiellońskiego, Kraków.

Knap R. (2016), Handel Polski z krajami Afryki-tendencje i potencjat rozwoju, „International Business and Global Economy”, 35(1).

Komor M. (2010), Modele komunikacji międzykulturowej, „Zeszyty Naukowe Uniwersytetu Szczecińskiego. Ekonomiczne Problemy Usług”, 55.

Kopiński D., Polus A., Tycholiz W. (2017), Afryka wielu prędkości, Polskie Centrum Studiów Afrykanistycznych, Wrocław.

Kowalik F. (2017), Tu żyja lwy, https://www.forbes.p1/przywodztwo/najbogatsze-kraje-afryki-podazaja-droga-bric/flgs53e (data dostępu: 12.09.2020).

KUKE (2020), Materiały informacyjne Korporacji Ubezpieczeń Kredytów Eksportowych, http://www.kuke.com.pl (data dostępu: 12.12.2020).

Macrotrends, WTI Crude Oil Prices, https://www.macrotrends.net/2516/wti-crude-oil-prices10-year-daily-chart (data dostępu: 28.11.2020).

McKinsey Global Institute (2016), Lions on the Move II: Realizing the Potential of Africa's Economies, https://www.mckinsey.com/featured-insights/middle-east-and-africa/lions-on-themove-realizing-the-potential-of-africas-economies\# (data dostępu: 30.11.2020).

Michałowski T. (2010), Integracja gospodarcza $w$ ramach COMESA jako przykład procesów integracyjnych w Afryce, [w:] H. Treder (red.), Problemy wspótczesnej gospodarki światowej, „Prace i Materiały Instytutu Handlu Zagranicznego UG", 29, Sopot.

Milczarek A. (2014), Africa as a new potential of the global economy, „Journal of International Studies", 2.

Munyama K. (2011), Economic growth and financial development in Sub-Saharan African countries, Poznań University of Economics Press, Poznań.

Munyama K., Kowalewska A. (2014), Wspótpraca gospodarcza Polski z krajami Afryki Subsaharyjskiej - szanse i zagrożenia, „Zeszyty Naukowe Wyższej Szkoły Gospodarki”, 21, seria: „Ekonomia”, 5: 173-192. 
Needham D. (1996), Business for Higher Awards, Wydawnictwo Heinemann Oxford.

Official and spoken languages of African countries, http://www.afrikanheritage.com/official-and-spoken-languages-of-african-countries (data dostępu: 25.11.2020).

Organizacja Narodów Zjednoczonych (2019), World Population Prospects 2019 Highlights, New York, https://population.un.org/wpp/Publications/Files/ WPP2019_Highlights.pdf (data dostępu: 30.11.2020).

Osiecki A. (2018), Warto zwiększyć sprzedaż do Afryki, https://www.rp.pl/Handel/306259895-Warto-zwiekszyc-sprzedaz-do-Afryki.html (data dostępu: 10.09.2020).

Pereltsvaig A. (2011), On official languages of sub-Saharan Africa, http://www. languagesoftheworld.info/student-papers/on-official-languages-of-sub-saharan (data dostępu: 25.11.2020).

Piórek M. (2017), Demokratyczna Republika Konga - afrykańska Golgota, https://opoka.org.pl/biblioteka/Z/ZM/som2017_kongo.html (data dostępu: 3.11.2020).

Polska Agencja Inwestycji i Handlu (2020), Rynki Zagraniczne, Afryka i Bliski Wschód. Przeglad wybranych gospodarek, https://www.paih.gov.pl/rynki zagraniczne/afryka_i_bliski_wschod (data dostępu: 15.09.2020).

Portal Promocji Eksportu (2020), Informacje o programie GoAfrica, http://www. trade (data dostępu: 12.12.2020).

Rymarczyk J. (1996), Internacjonalizacja przedsiębiorstwa, Polskie Wydawnictwo Ekonomiczne, Warszawa.

Rynarzewski T., Nawrot K.A., Zajączkowski K., Cieślik E. (2017), Potencjał gospodarczy i możliwości rozwojowe Afryki. Polska perspektywa, Polskie Wydawnictwo Ekonomiczne SA, Warszawa.

Szukalski S.M. (2013), Uwarunkowania i perspektywy rozwoju ekonomicznego Afryki Subsaharyjskiej, „Studia Ekonomiczne”, 2(77).

The World Factbook (2017), https://www.cia.gov/library/publications/download/ download 2017/index.html (data dostępu: 16.11.2020).

Transparency International (2019), https://www.transparency.org/cpi2019?/news/ feature/cpi (data dostępu: 25.11.2020).

UNCTAD (2020a), Annual average growth rate, https://unctadstat.unctad.org/ wds/TableViewer/tableView.aspx (data dostępu: 16.11.2020).

UNCTAD (2020b), Country profiles, https://unctadstat.unctad.org/CountryProfile/GeneralProfile/en-GB/276/index.html (data dostępu: 16.11.2020).

UNCTAD (2020c), Merchandise trade matrix, https://unctadstat.unctad.org/wds/ TableViewer/tableView.aspx (data dostępu: 16.11.2020).

UNCTAD (2020d), Total and urban population, annual, https://unctadstat.unctad.org/ wds/TableViewer/tableView.aspx?ReportId=97 (data dostępu: 16.11.2020). 
UNEP (2017), Atlas of Africa Energy Resources 2017, https://www.afdb.org/en/ documents/document/atlas-of-africa-energy-resources109425 (data dostępu: 20.09.2020).

Wójtowicz B., Posthumus L. (2016), Droga ku wielojęzyczności RPA, „Afryka", 44, http://cejsh.icm.edu.pl/cejsh/element/bwmeta1.element.desklight-d12673c7-d1ac43f1-bc49-ea943227a2c0/c/afryka_44_wojtowicz_posthumus.pdf (data dostępu: 28.11.2020).

Zajączkowski K. (2016), Polska na wschodzacych rynkach Afryki Subsaharyjskiej na przykładzie RPA, „Afryka”, 43, http://cejsh.icm.edu.pl/cejsh/element/ bwmeta1.element.desklight-529733f2-774c4a25-a038-8299a5e5da1c/c/ afryka_43_Zajaczkowski.pdf (data dostępu: 28.11.2020).

\section{Summary}

\section{Export opportunities for Polish enterprises on the selected markets of Sub-Saharan Africa}

The article outlines foreign expansion possibilities for Polish enterprises through exports to the markets of Sub-Saharan African countries. The analysis of chosen economic and social factors on these markets proved that despite the large differentiation and the political, social and economic instability, SubSaharan countries are the region of a high economic growth rate. According to experts these are promising markets, which will not only become one of the most attractive within the next decade, but also will drive the world economic growth soon. However, the analysis conducted in the article confirmed that Polish exporters do not make use of an export potential of Sub-Saharan countries. The authors of the text indicate the main reasons of such a state of affairs and formulate recommendations for Polish exporters who are considering export to African countries. Particular attention has been paid to such aspects as a proper marketing strategy preparation, successful export process planning and understanding the cultural differences impact on business. Additionally, the article contains a brief characteristic of the highest risk factors and the key factors that determine success of export expansion to the markets of Sub-Saharan Africa.

Keywords: export, Poland, Sub-Saharan Africa, economic growth, export strategy, marketing strategy 